\title{
Analisis Tingkat Kenyamanan Celana Panjang Wanita Menggunakan Pola Sistem Porrie Muliawan dan Sistem Praktis pada Ukuran Xxl
}

\author{
Selli Vorensia, Idah Hadijah*, Nurul Aini \\ Universitas Negeri Malang, Jl. Semarang No. 5 Malang, Jawa Timur, Indonesia \\ *Penulis korespondensi, Surel: idahrohman@um.ac.id
}

Paper received: 06-04-2021; revised: 22-04-2021; accepted: 27-04-2021

\begin{abstract}
The snug circumference is the part of the pants that needs to be considered, because this part affects the comfort of the pants when used to move. The purpose of this study was to analyze the comfort of women's trousers using the Porrie Muliawan System Pattern and the Practical System in XXL Size. This research is a type of descriptive research with a quantitative approach. There are two populations that will be discussed, namely the respondent population and the panelist population. Based on the results of the study, it can be concluded that the comfort level of women's trousers with the Porrie Muliawan system at size XXL in terms of the level of static comfort and the level of kinetic comfort is included in the comfortable category. The comfort level of practical women's trousers at size XXL in terms of the level of static comfort and the level of kinetic comfort is included in the less comfortable category. kinetics is included in the comfortable category.
\end{abstract}

Keywords: comfort; women's trousers; porrie muliawan system; praktis system

\begin{abstract}
Abstrak
Lingkar pesak merupakan bagian celana yang perlu diperhatikan, karena pada bagian ini memengaruhi kenyamanan celana saat digunakan untuk bergerak. Tujuan penelitian ini adalah menganalisis Kenyamanan Celana Panjang Wanita Menggunakan Pola Sistem Porrie Muliawan dan Sistem Praktis pada Ukuran XXL. Penelitian ini merupakan jenis penelitian deskriptif dengan pendekatan kuantitatif. Terdapat dua populasi yang akan dibahas yaitu mengenai populasi responden dan populasi panelis. Berdasarkan hasil penelitian, dapat diambil kesimpulan bahwa tingkat kenyamanan celana panjang wanita sistem Porrie Muliawan pada ukuran XXL ditinjau dari tingkat kenyamanan statis dan tingkat kenyamanan kinetis termasuk dalam kategori nyaman. Tingkat kenyamanan celana panjang wanita sistem Praktis pada ukuran XXL ditinjau dari tingkat kenyamanan statis dan tingkat kenyaman kinetis termasuk dalam kategori kurang nyamanBerdasarkan hasil penelitian, dapat diambil kesimpulan bahwa tingkat kenyamanan celana panjang wanita sistem Porrie Muliawan pada ukuran XXL ditinjau dari tingkat kenyamanan statis dan tingkat kenyamanan kinetis termasuk dalam kategori nyaman.
\end{abstract}

Kata kunci: kenyamanan; celana panjang wanita; sistem porrie muliawan; sistem praktis

\section{Pendahuluan}

Busana merupakan salah satu kebutuhan pokok setiap manusia. Pengertian dari busana adalah segala sesuatu yang digunakan mulai dari ujung rambut hingga ujung kaki dilengkapi dengan pelengkap busana sehingga akan memberikan kenyamanan dan keindahan bagi si pemakai. Busana berfungsi sebagai pelindung tubuh, menutupi kekurangan, dan memenuhi syarat kesusilaan. Menurut Ernawati (2008) bentuk dasar busana Indonesia pada zaman dahulu awalnya hanya ada lima tipe yaitu kutang, pakaian bungkus, poncho, celana, dan bentuk kaftan. Perkembangan zaman yang semakin maju membuat busana juga mengalami perubahan dan perkembangan. Salah satu penggolongan busana yang mengalami perubahan dan 
perkembangan adalah busana pokok. Penggolongan busana pokok meliputi blus, rok, celana, gaun, dan kebaya.

Lingkar pesak merupakan bagian celana yang perlu diperhatikan, karena pada bagian ini akan mempengaruhi kenyamanan celana saat digunakan untuk bergerak. Hasil jadi lingkar pesak yang terlalu kecil akan membuat pesak ikut tertarik, sehingga ketika digunakan akan terasa tidak nyaman. Beberapa peneliti diantaranya seperti Widiastutik dan Khotimah sudah meneliti mengenai hal ini, namun ukuran yang digunakan adalah ukuran standar yaitu ukuran M. Widiastutik (2013) menyebutkan bahwa analisis pembuatan celana panjang wanita menggunakan pola sistem Porrie Muliawan ditinjau dari titik pas (fitting factor) untuk ukuran "M" SNI hasilnya lebih baik dibandingkan pola sistem Soekarno. Sedangkan hasil penelitian Khotimah (2007) dijelaskan bahwa celana panjang wanita ukuran M pola sistem Praktis hasilnya lebih baik daripada pola sistem Soekarno. Berdasarkan kedua hasil penelitian tersebut, sistem Porrie Muliawan dan sistem Praktis pada ukuran M sudah terbukti nyaman digunakan. Penulis memilih ukuran M sebagai acuan karena ukuran ini untuk tubuh ideal. "Ukuran S untuk orang dewasa yang berbadan kecil dan ukuran M untuk orang dewasa yang berbadan sedang" (Wancik, 2006).

Maulidya (2012) adalah salah satu peneliti yang meneliti mengenai tingkat kenyamanan celana panjang wanita dengan ukuran celana big size terutama pada ukuran XXXXL. Hasil penelitian menunjukkan bahwa celana panjang wanita sistem Wancik sangat tidak nyaman jika dipakai dan perlu adanya tindak lanjut penelitian dengan menggunakan sistem pola lain. Berdasarkan hasil penelitian tersebut, penulis ingin menindaklanjuti dengan menggunakan ukuran celana big size yaitu ukuran XXL. Ukuran ini dipilih karena ukuran celana big size seperti yang telah dijelaskan sebelumnya adalah ukuran yang lebih besar dari ukuran XL. Menurut Soewardi (2008) menjelaskan bahwa ukuran tubuh wanita Indonesia sangat beragam mulai dari ukuran XS hingga XXXL. Hal ini membuat peneliti tidak menggunakan ukuran celana big size yaitu XXXXL seperti penelitian sebelumnya, melainkan menggunakan ukuran XXL.

Pola yang digunakan adalah pola sistem Porrie Muliawan dan sistem Praktis pada celana panjang wanita model slack. Seperti yang telah dijelaskan sebelumnya, kedua sistem pola ini sudah terbukti nyaman digunakan pada ukuran $\mathrm{M}$, namun belum dapat ditentukan apakah kedua sistem tersebut juga nyaman digunakan pada ukuran XXL. Berdasarkan hal tersebut, dalam penelitian ini peneliti akan meneliti tentang "Analisis Tingkat Kenyamanan Celana Panjang Wanita Menggunakan Pola Sistem Porrie Muliawan dan Sistem Praktis pada Ukuran XXL".

\section{Metode}

Penelitian ini merupakan jenis penelitian deskriptif dengan pendekatan kuantitatif. Terdapat dua populasi yang akan dibahas yaitu mengenai populasi responden dan populasi panelis. Populasi responden dalam penelitian ini adalah mahasiswa S1 Pendidikan Tata Busana Universitas Negeri Malang angkatan 2015-2018 yang memiliki ukuran celana sesuai dengan ukuran standar XXL dan memiliki tinggi $\pm 170 \mathrm{~cm}$. Populasi panelis adalah dosen tata busana Universitas Negeri Malang yang menguasai materi mengenai celana panjang wanita. Sampel yang digunakan adalah sampel jenuh, di mana semua anggota populasi menjadi anggota. Instrumen penelitian berupa lembar pengamatan yang ditujukan kepada ketiga responden dan ketiga panelis. Lembar pengamatan terdiri dari dua sub variabel pada setiap sistem pola, yaitu tingkat kenyamanan statis dan tingkat kenyamanan kinetis. Tingkat 
kenyamanan statis terdiri dari tujuh indikator sedangkan tingkat kenyamanan kinetis terdiri dari lima indikator. Skala yang digunakan yaitu skala likert dan uji instrumen menggunakan uji validitas konstrak menururt para ahli. Teknik pengumpulan data dilakukan dengan observasi dan angket. Teknik analisis data yang digunakan adalah analisis persentase, dengan tahapantahapan berupa (1) pemberian skor (2) tabulasi data (3) uji statistika (4) interpretasi data.

\section{Hasil dan Pembahasan}

\subsection{Analisis Tingkat Kenyamanan Celana Panjang Wanita Menggunakan Sistem Porrie Muliawan pada Ukuran XXL}

\subsubsection{Tingkat Kenyamanan Statis}

Statis menurut Kamus Besar Bahasa Indonesia (KBBI) adalah segala sesuatu yang dilakukan dalam keadaan diam, seperti tidak bergerak, tidak aktif, dan tidak berubah tempat (tetap). Tingkat kenyamanan statis dalam penelitian ini meliputi titik pas (fitting factor), ukuran, dan hasil jahitan. Terdapat tujuh kriteria yang diamati oleh ketiga responden dan ketiga panelis, yaitu lingkar pinggang, lingkar panggul, lingkar paha, lingkar pesak, lingkar lutut, pipa celana, serta lingkar pergelangan kaki. Setiap kriteria memiliki sub kriteria, sehingga total kriteria dalam tingkat kenyamanan statis adalah 16 kriteria.

\subsection{1. $\quad$ Lingkar Pinggang}

Aldrich dalam Maryam (2007) mengatakan bahwa lingkar pinggang dikatakan tepat apabila bagian belakang lingkar pinggang tidak menggelembung dan letak ban pinggang tepat pada garis pinggang. Hasil penelitian menunjukkan bahwa lingkar pinggang termasuk dalam kategori nyaman, karena ukuran lingkar pinggang cukup dan letak lingkar pinggang berada tepat pada garis pinggang. Persentase yang diperoleh dari hasil pengamatan responden sebanyak $100 \%$ dan persentase dari hasil pengamatan panelis sebanyak $88,89 \%$.

\subsubsection{Lingkar Panggul}

Aldrich dalam Maryam (2007) mengatakan bahwa lingkar panggul yang baik adalah yang terletak pada garis panggul terbesar dan bentuknya sesuai dengan bentuk panggul wanita pada umumnya. Hasil penelitian menunjukkan bahwa lingkar panggul termasuk dalam kategori nyaman, karena ukuran lingkar pinggang cukup dan letaknya tepat, namun bentuk panggul sedikit terlalu lebar sehingga terlihat "nguping". Nguping adalah istilah dalam tata busana yang biasanya digunakan untuk menyatakan bagian busana yang terlalu lebar sehingga bentuknya seperti telinga. Hal ini disebabkan oleh pembuatan pola yang kurang baik dan tepat pada lingkar panggul sehingga mempengaruhi pipa celana secara keseluruhan. Persentase yang diperoleh dari hasil pengamatan responden dan panalis masing-masing sebanyak $88,89 \%$.

\subsubsection{3. $\quad$ Lingkar Paha}

Aldrich dalam Maryam (2007) mengatakan bahwa untuk kriteria lingkar paha yang baik yaitu letaknya terdapat pada lingkar paha terbesar atau pangkal paha dan tidak terdapat kerutan. Hasil penelitian menunjukkan bahwa lingkar paha termasuk dalam kategori nyaman, karena ukuran lingkar paha cukup dan letaknya tepat pada bagian lingkar paha. Persentase 
yang diperoleh dari hasil pengamatan responden sebanyak 100\% dan persentase dari hasil pengamatan panelis sebanyak $77,78 \%$.

\subsubsection{Lingkar Pesak}

Aldrich dalam Maryam (2007) menjelaskan bahwa lingkar pesak yang baik yaitu lingkar pesak yang tidak terdapat kerutan pada bagian depan dan belakang, tidak terlalu panjang, tidak berkerut pada sekeliling lingkar panggul dan sisi. Hasil penelitian menunjukkan bahwa lingkar pesak termasuk dalam kategori nyaman, karena letak lingkar pesak tepat, ukurannya cukup, dan hasil jadi jahitan lingkar pesak tidak berkerut. Persentase yang diperoleh dari hasil pengamatan responden sebanyak $88,89 \%$ dan persentase dari hasil pengamatan panelis sebanyak $100 \%$.

\subsubsection{Lingkar Lutut}

Wright dalam Widiastutik (2013) menjelaskan bahwa pada bagian lingkar lutut tepat pada garis lutut dan pada sekeliling lingkar lutut tidak berkerut. Hasil penelitian menunjukkan bahwa lingkar lutut termasuk dalam kategori kurang nyaman, karena ukuran lingkar lutut cukup namun letak lingkar lutut tidak berada tepat pada garis lutut. Hal ini disebabkan karena saat pembuatan pola pada sistem Porrie Muliawan letak garis lutut tidak dikurangi dan hanya dibagi dua mulai dari lingkar paha hingga lingkar pergelangan kaki. Persentase yang diperoleh dari hasil pengamatan responden sebanyak $77,78 \%$ dan persentase dari hasil pengamatan panelis sebanyak $55,56 \%$.

\subsubsection{Pipa Celana}

Wright dalam Widiastutik (2013) menjelaskan bahwa bagian sisi pipa celana tidak tertarik dan tidak terdapat kerutan. Hasil penelitian menunjukkan bahwa pipa celana termasuk dalam kategori nyaman, karena ukuran pipa celana cukup dan bentuknya rapi sehingga tidak tertarik, namun bagian bentuk lingkar panggul yang kurang tepat dan terlalu lebar "nguping" membuat pipa celana bagian atas menggelembung. Persentase yang diperoleh dari hasil pengamatan responden $\%$ dan panelis masing-masing sebanyak $88,89 \%$.

\subsubsection{Lingkar Pergelangan Kaki}

Wright dalam Widiastutik (2013) mengatakan bahwa lingkar pergelangan kaki dikatakan baik jika letak lingkar kaki tampak rata, sekeliling lingkar pergelangan kaki tidak sempit, dan terletak di bawah mata kaki. Hasil penelitian menunjukkan bahwa lingkar pergelangan kaki termasuk dalam kategori nyaman karena letaknya tepat pada bawah mata kaki dan ukurannya cukup. Persentase yang diperoleh dari hasil pengamatan responden sebanyak $100 \%$ dan persentase dari hasil pengamatan panelis sebanyak 88,89\%. Berdasarkan uraian hasil penelitian di atas, dapat diketahui bahwa hasil penilaian tingkat kenyamanan celana panjang wanita menggunakan sistem Porrie Muliawan pada ukuran XXL ditinjau dari tingkat kenyamanan statis dengan kategori nyaman $71,43 \%$, kategori kurang nyaman $21,43 \%$, dan kategori tidak nyaman 7,14\%.

\subsubsection{Tingkat Kenyamanan Kinetis}


Kinetis menurut Kamus Besar Bahasa Indonesia (KBBI) adalah kata lain dari gerak, segala sesuatu yang dilakukan dengan cara bergerak. Kinetis dalam penelitian ini berupa sikap atau aktivitas yang dilakukan dengan cara bergerak, tujuannya untuk mengetahui tingkat kenyamanan. Tingkat kenyamanan kinetis meliputi cara melakukan aktivitas tersebut, ukuran, dan hasil jahitan. Tingkat kenyamanan kinetis terdiri dari lima kriteria. Setiap kriteria memiliki sub kriteria, sehingga total kriterianya adalah 12 kriteria.

\subsubsection{Duduk di Kursi}

Hasil penelitian menunjukkan bahwa duduk di kursi termasuk dalam kategori nyaman, karena mudah digunakan untuk duduk di kursi, tidak terdapat bagian celana yang tertarik, dan saat duduk lingkar pinggang tidak tertekan serta letak lingkar pinggang tetap berada pada garis pinggang sehingga nyaman digunakan. Persentase yang diperoleh dari hasil pengamatan responden sebanyak $100 \%$ dan persentase dari hasil pengamatan panelis sebanyak $88,89 \%$.

\subsubsection{Duduk di Lantai (Bersila)}

Hasil penelitian menunjukkan bahwa duduk di lantai (bersila) termasuk dalam kategori nyaman, karena mudah untuk duduk di lantai (bersila), letak lingkar pinggang berada tepat pada garis pinggang, dan tidak ada bagian yang tertarik saat digunakan duduk di lantai (besila). Persentase yang diperoleh dari hasil pengamatan responden sebanyak 88,89\% dan persentase dari hasil pengamatan panelis sebanyak 77,78\%.

\subsubsection{Jongkok}

Hasil penelitian menunjukkan bahwa jongkok termasuk dalam kategori nyaman, karena mudah untuk jongkok yaitu dari posisi berdiri langsung jongkok tanpa menaikkan celana terlebih dahulu, letak lingkar pinggang berada tepat pada garis pinggang, dan tidak terdapat bagian yang tertarik. Persentase yang diperoleh dari hasil pengamatan responden dan panelis masing-masing sebanyak $77,78 \%$.

\subsubsection{Berjalan}

Hasil penelitian menunjukkan bahwa berjalan termasuk dalam kategori nyaman, karena mudah untuk berjalan maupun lari, letak lingkar pinggang tepat, dan tidak ada bagian yang tertarik termasuk pesak sehingga nyaman digunakan untuk berjalan. Persentase yang diperoleh dari hasil pengamatan responden dan panelis masing-masing sebanyak $100 \%$.

\subsubsection{Bergerak}

Hasil penelitian menunjukkan bahwa bergerak termasuk dalam kategori nyaman, karena mudah untuk bergerak seperti jalan di tempat maupun gaya olahraga. Letak lingkar pinggang juga tepat serta tidak ada bagian yang tertarik jika digunakan untuk bergerak seperti apapun. Persentase yang diperoleh dari hasil pengamatan responden sebanyak $100 \%$ dan persentase dari hasil pengamatan panelis sebanyak 88,89\%. Malik \& Sinsha (2012) menjelaskan bahwa kenyamanan busana dapat dilihat ketika busana tersebut digunakan maka tidak merasa terganggu, aman, bebas untuk bergerak, tidak sempit atau longgar. Penjelasan ini sudah termasuk dalam setiap bagian celana panjang wanita yang telah diuraikan di atas. Berdasarkan hasil penelitian uraian di atas, dapat diketahui bahwa hasil penilaian tingkat 
kenyamanan celana panjang wanita menggunakan sistem Porrie Muliawan pada ukuran XXL ditinjau dari tingkat kenyamanan kinetis dengan kategori nyaman 70\%, kategori kurang nyaman $30 \%$, dan kategori tidak nyaman $0 \%$.

\subsection{Analisis Tingkat Kenyamanan Celana Panjang Wanita Menggunakan Sistem Praktis pada Ukuran XXL}

\subsubsection{Tingkat Kenyamanan Statis}

Statis menurut Kamus Besar Bahasa Indonesia (KBBI) adalah segala sesuatu yang dilakukan dalam keadaan diam, seperti tidak bergerak, tidak aktif, dan tidak berubah tempat (tetap). Tingkat kenyamanan statis dalam penelitian ini meliputi titik pas (fitting factor), ukuran, dan hasil jahitan. Terdapat tujuh kriteria yang diamati oleh ketiga responden dan ketiga panelis, yaitu lingkar pinggang, lingkar panggul, lingkar paha, lingkar pesak, lingkar lutut, pipa celana, serta lingkar pergelangan kaki. Setiap kriteria memiliki sub kriteria, sehingga total kriteria dalam tingkat kenyamanan statis adalah 16 kriteria.

\subsubsection{1. $\quad$ Lingkar Pinggang}

Aldrich dalam Maryam (2007) mengatakan bahwa lingkar pinggang dikatakan tepat apabila bagian belakang lingkar pinggang tidak menggelembung dan letak ban pinggang tepat pada garis pinggang. Hasil penelitian menunjukkan bahwa lingkar pinggang termasuk dalam kategori nyaman, karena ukuran lingkar pinggang cukup dan letak lingkar pinggang berada tepat pada garis pinggang. Persentase yang diperoleh dari hasil pengamatan responden sebanyak $100 \%$ dan persentase dari hasil pengamatan panelis sebanyak $88,89 \%$.

\subsubsection{Lingkar Panggul}

Aldrich dalam Maryam (2007) mengatakan bahwa lingkar panggul yang baik adalah yang terletak pada garis panggul terbesar dan bentuknya sesuai dengan bentuk panggul wanita pada umumnya. Hasil penelitian menunjukkan bahwa lingkar panggul termasuk dalam kategori kurang nyaman, karena ukuran lingkar pinggang cukup, namun bentuk panggul yang lebar dan besar "nguping" membuat ukuran lingkar panggul terlalu besar. Hal ini disebabkan oleh ketika membuat pola kurang memperhatikan hasil jadi bentuk panggul. Persentase yang diperoleh dari hasil pengamatan responden sebanyak $77,78 \%$ dan persentase dari hasil pengamatan panelis sebanyak $88,89 \%$.

\subsubsection{Lingkar Paha}

Aldrich dalam Maryam (2007) mengatakan bahwa untuk kriteria lingkar paha yang baik yaitu letaknya terdapat pada lingkar paha terbesar atau pangkal paha dan tidak terdapat kerutan. Hasil penelitian menunjukkan bahwa lingkar paha termasuk dalam kategori nyaman, karena ukuran lingkar paha cukup dan letaknya tepat pada bagian lingkar paha. Persentase yang diperoleh dari hasil pengamatan responden sebanyak $77,78 \%$ dan persentase dari hasil pengamatan panelis sebanyak $55,56 \%$.

\subsubsection{Lingkar Pesak}


Aldrich dalam Maryam (2007) menjelaskan bahwa lingkar pesak yang baik yaitu lingkar pesak yang tidak terdapat kerutan pada bagian depan dan belakang, tidak terlalu panjang, tidak berkerut pada sekeliling lingkar panggul dan sisi. Hasil penelitian menunjukkan bahwa lingkar pesak termasuk dalam kategori nyaman, karena letak lingkar pesak tepat, ukurannya cukup, dan hasil jadi jahitan lingkar pesak tidak berkerut pada bagian depan maupun belakang, namun sedikit bervolume pada bagian belakang lingkar pesak. Persentase yang diperoleh dari hasil pengamatan responden sebanyak $88,89 \%$ dan persentase dari hasil pengamatan panelis sebanyak $100 \%$.

\subsubsection{Lingkar Lutut}

Wright dalam Widiastutik (2013) menjelaskan bahwa pada bagian lingkar lutut tepat pada garis lutut dan pada sekeliling lingkar lutut tidak berkerut. Hasil penelitian menunjukkan bahwa lingkar lutut termasuk dalam kategori kurang nyaman, karena ukuran lingkar lutut cukup namun letak lingkar lutut tidak berada tepat pada garis lutut. Hal ini disebabkan oleh panduan membuat pola sistem Praktis pada bagian lingkar lutut dari lingkar paha hingga lingkar pergelangan kaki, sudah diukur dan dikurangi 3-4 cm namun hasil jadi letak lingkar lutut masih berada di bawah garis lutut dan tidak tepat pada garis lutut yang sesungguhnya. Persentase yang diperoleh dari hasil pengamatan responden sebanyak 77,78\% dan persentase dari hasil pengamatan panelis sebanyak $55,56 \%$.

\subsubsection{Pipa Celana}

Wright dalam Widiastutik (2013) menjelaskan bahwa bagian sisi pipa celana tidak tertarik dan tidak terdapat kerutan. Hasil penelitian menunjukkan bahwa pipa celana termasuk dalam kategori nyaman, karena ukuran pipa celana cukup dan nagian sisi celana tidak tertarik, namun bentuk pipa celana bagian atas menggelembung. Hal ini disebabkan oleh lingkar panggul yang terlalu lebar dan besar "nguping" mengakibatkan hasil jadi pipa celana secara keseluruhan kurang baik. Persentase yang diperoleh dari hasil pengamatan responden sebanyak 77,78\% dan persentase dari hasil pengamatan panelis sebanyak $88,89 \%$.

\subsubsection{Lingkar Pergelangan Kaki}

Wright dalam Widiastutik (2013) mengatakan bahwa lingkar pergelangan kaki dikatakan baik jika letak lingkar kaki tampak rata, sekeliling lingkar pergelangan kaki tidak sempit, dan terletak di bawah mata kaki. Hasil penelitian menunjukkan bahwa lingkar pergelangan kaki termasuk dalam kategori nyaman karena letaknya tepat pada bawah mata kaki dan ukurannya juga cukup. Persentase yang diperoleh dari hasil pengamatan responden dan panelis masing-masing sebanyak $100 \%$. Berdasarkan hasil penelitian uraian di atas, dapat diketahui bahwa hasil penilaian tingkat kenyamanan celana panjang wanita menggunakan sistem Porrie Muliawan pada ukuran XXL ditinjau dari tingkat kenyamanan statis dengan kategori nyaman $61,91 \%$, kategori kurang nyaman $28,58 \%$, dan kategori tidak nyaman 9,53\%.

\subsubsection{Tingkat Kenyamanan Kinetis}

Kinetis menurut Kamus Besar Bahasa Indonesia (KBBI) adalah kata lain dari gerak, segala sesuatu yang dilakukan dengan cara bergerak. Kinetis dalam penelitian ini berupa sikap atau aktivitas yang dilakukan dengan cara bergerak, tujuannya untuk mengetahui tingkat kenyamanan. Tingkat kenyamanan kinetis meliputi cara melakukan aktivitas tersebut, ukuran, 
dan hasil jahitan. Tingkat kenyamanan kinetis terdiri dari lima kriteria. Setiap kriteria memiliki sub kriteria, sehingga total kriterianya adalah 12 kriteria.

\subsubsection{Duduk di Kursi}

Hasil penelitian menunjukkan bahwa duduk di kursi termasuk dalam kategori kurang nyaman, karena sedikit sulit untuk duduk di kursi, tidak terdapat bagian celana yang tertarik, letak lingkar pinggang tepat pada garis pinggang, namun saat duduk di kursi lingkar pinggang bagian depan sedikit tertekan dan bagian belakang terdapat volume. Persentase yang diperoleh dari hasil pengamatan responden sebanyak $77,78 \%$ dan persentase dari hasil pengamatan panelis sebanyak $44,44 \%$.

\subsubsection{Duduk di Lantai (Bersila)}

Hasil penelitian menunjukkan bahwa duduk di lantai (bersila) termasuk dalam kategori kurang nyaman, penjelasannya hampir sama seperti duduk di kursi. Letak lingkar pinggang tepat pada garis pinggang, namun pada bagian depan sedikit tertekan dan bagian belakang bervolume. Tidak ada bagian celana yang tertarik, namun jika digunakan untuk duduk di lantai (bersila) sedikit sulit. Persentase yang diperoleh dari hasil pengamatan responden sebanyak $77,78 \%$ dan persentase dari hasil pengamatan panelis sebanyak $66,67 \%$.

\subsubsection{Jongkok}

Hasil penelitian menunjukkan bahwa jongkok termasuk dalam kategori kurang nyaman, karena sedikit sulit untuk jongkok yaitu dari posisi berdiri ke posisi jongkok perlu menaikkan celana terlebih dahulu. Terdapat bagian celana yang tertarik ketika jongkok, seperti lingkar paha, lingkar lutut, dan lingkar pergelangan kaki. Lingkar pergelangan kaki saat digunakan untuk jongkok tertarik ke atas dan tertahan oleh betis sehingga kurang nyaman digunakan, namun letak lingkar pinggang berada tepat pada garis pinggang. Persentase yang diperoleh dari hasil pengamatan responden sebanyak $77,78 \%$ dan persentase dari hasil pengamatan panelis sebanyak $66,67 \%$.

\subsubsection{Berjalan}

Hasil penelitian menunjukkan bahwa berjalan termasuk dalam kategori nyaman, karena mudah untuk berjalan maupun lari, letak lingkar pinggang tepat, dan tidak ada bagian yang tertarik termasuk pesak sehingga nyaman digunakan untuk berjalan. Persentase yang diperoleh dari hasil pengamatan responden dan panelis masing-masing sebanyak $100 \%$.

\subsubsection{Bergerak}

Hasil penelitian menunjukkan bahwa bergerak termasuk dalam kategori nyaman, karena mudah untuk bergerak seperti jalan di tempat maupun gaya olahraga. Letak lingkar pinggang juga tepat serta tidak ada bagian yang tertarik jika digunakan untuk bergerak seperti apapun. Persentase yang diperoleh dari hasil pengamatan responden sebanyak $100 \%$ dan persentase dari hasil pengamatan panelis sebanyak 88,89\%. Malik \& Sinsha (2012) 
menjelaskan bahwa kenyamanan busana dapat dilihat ketika busana tersebut digunakan maka tidak merasa terganggu, aman, bebas untuk bergerak, tidak sempit atau longgar. Penjelasan ini sudah termasuk dalam setiap bagian celana panjang wanita yang telah diuraikan di atas. Berdasarkan hasil penelitian uraian di atas, dapat diketahui bahwa hasil penilaian tingkat kenyamanan celana panjang wanita menggunakan sistem Porrie Muliawan pada ukuran XXL ditinjau dari tingkat kenyamanan kinetis dengan kategori nyaman 46,67\%, kategori kurang nyaman $46,67 \%$, dan kategori tidak nyaman $6,67 \%$.

\section{Simpulan}

Tingkat kenyamanan celana panjang wanita menggunakan pola sistem Porrie Muliawan pada ukuran XXL ditinjau dari tingkat kenyamanan statis, hasil keseluruhan termasuk dalam kategori nyaman. Persentase kategori nyaman sebanyak 71,43\%, kategori kurang nyaman sebanyak 21,43\%, dan kategori tidak nyaman sebanyak 7,14\% sedangkan tingkat kenyamanan kinetis, hasil keseluruhan termasuk dalam kategori nyaman. Persentase kategori nyaman sebanyak 70\%, kategori kurang nyaman sebanyak 30\%, dan kategori tidak nyaman sebanyak $0 \%$. Tingkat kenyamanan celana panjang wanita menggunakan pola sistem Praktis pada ukuran XXL ditinjau dari tingkat kenyamanan statis, hasil keseluruhan termasuk dalam kategori kurang nyaman. Persentase kategori nyaman sebanyak 61,91\%, kategori kurang nyaman sebanyak 28,58\%, dan kategori tidak nyaman sebanyak 9,53\% sedangkan tingkat kenyamanan kinetis, hasil keseluruhan termasuk dalam kategori kurang nyaman. Persentase kategori nyaman sebanyak 46,67\%, kategori kurang nyaman sebanyak 46,67\%, dan kategori tidak nyaman sebanyak $6,67 \%$.

Kelebihan sistem Porrie Muliawan yaitu ukuran setiap bagian celana cukup, letak bagian celana tepat, dan nyaman digunakan untuk bergerak dengan berbagai macam gerakan. Kekurangan sistem Porrie Muliawan adalah letak lingkar lutut lebih ke bawah dari garis lutut dan bentuk panggul terkesan terlalu lebar dan besar "nguping" sehingga hasil jadi pipa celana bagian atas terlalu menggelembung. Kelebihan dari sistem Praktis yaitu letak lingkar lutut tidak terlalu ke bawah dari garis lutut, sedangkan kekurangannya adalah saat digunakan untuk duduk di kursi, duduk di lantai (bersila), dan jongkok pada lingkar pinggang bagian depan tertekan serta bagian belakang bervolume. Bentuk bagian panggul terkesan lebar dan besar "nguping" sehingga hasil jadi pipa celana secara keseluruhan pada bagian atas menggelembung. Kekurangan gerakan jongkok yaitu terdapat bagian yang tertarik, seperti lingkar paha, lingkar lutut, dan lingkar pergelangan kaki. Lingkar pergelangan kaki saat digunakan untuk jongkok tertarik ke atas dan tertahan oleh betis sehingga kurang nyaman digunakan.

\section{Daftar Rujukan}

Depdiknas. 2014. Kamus Besar Bahasa Indonesia. Jakarta: Gramedia Pustaka Utama.

Ernawati, I., \& Nelmira, W. (2008). Tata busana jilid 2. Jakarta. Direktorat pembinaan sekolah menengah kejuruan, Direktorat jendral manajemen, pendidikan dasar dan menengah, Departemen Pendidikan Nasional.

Khotimah, K. (2007). Perbedaan hasil pembuatan celana panjang wanita yang menggunakan pola sistem soekarno dan sistem praktis dengan ukuran $S, M, L$ (Doctoral dissertation, Universitas Negeri Semarang).

Malik, T., \& Sinha, T. K. (2012). Clothing comfort: A key parameter in clothing. Pakistan Textile Journal, 61(1).

Maryam, S. (2007). Analisis Pola Celana Metode Winifred Aldrich dengan Ukuran Standar S, M, L. Skripsi tidak diterbitkan. Surabaya: FT UNESA. 
Jurnal Inovasi Teknik dan Edukasi Teknologi, 1(4), 2021, 315-324

Maulidya, N. E. (2012). Analisis tingkat kenyamanan pola celana panjang wanita sistem wancik untuk ukuran XXXXL (Doctoral dissertation, Universitas Negeri Malang).

Soewardi, C. (2008). Mix \& Match Busana Batik Untuk Anak dan Remaja. Jakarta: Gramedia Pustaka Utama.

Wancik, M. H. (2006). Bina Busana Pelajaran Menjahit Pakaian Wanita Buku 2. Jakarta: Gramedia.

Widiastutik, Y. (2013). Analisa pembuatan celana panjang wanita menggunakan pola sistem soekarno dan sistem porrie muliawan ditinjau dari titik pas (fiting factor) untuk ukuran" m" sni. Skripsi Jurusan Tata Busana-Fakultas Teknik UM.

Makmara, T. (2010). Tuturan Persuasif Wiraniaga dalam Berbahasa Indonesia: Kajian Etnografi Komunikasi.(Disertasi). DISERTASI dan TESIS Program Pascasarjana UM. 